\title{
ANALISIS CUACA EKSTREM TERKAIT BENCANA HIDROMETEOROLOGI DI JAYAPURA (STUDI KASUS HUJAN LEBAT TANGGAL 22 FEBRUARI 2014)
}

\author{
Pande Made Rony Kurniawan \\ Stasiun Meteorologi Kelas I Hang Nadim, Batam \\ Email: pandemaderonykurniawan@gmail.com
}

\begin{abstract}
ABSTRAK
Hujan dengan intensitas sangat lebat sebesar 240.0 mm yang terjadi tanggal 22 Februari 2014 di Kabupaten Jayapura menyebabkan banjir dan tanah longsor dibeberapa distrik. Analisis cuaca diperlukan untuk mengetahui faktor-faktor meteorologi serta meningkatkan kesiapsiagaan yang berguna untuk mengurangi dampak dan kerugian akibat bencana hidrometeorologi. Data suhu muka laut, anomali suhu muka laut, indeks osilasi selatan serta peta medan angin di interpretasi secara visual. Data satelit MTSAT diolah menggunakan aplikasi SATAID 6.02 untuk menghasilkan luaran berupa gambar dan grafik seri waktu dari suhu dan tinggi puncak awan. Data angin komponen zonal dan meridional serta kelembapan relatif diolah menggunakan program Grads 1.9.0 untuk menghasilkan luaran berupa vortisitas, pola angin dan kelembapan udara tiap lapisan udara. Data pengamatan udara atas dalam bentuk sandi Temp diolah menggunakan aplikasi Raob 5.7 untuk mendapatkan indeks-indeks kemantapan udara. Dari hasil analisis didapatkan adanya Daerah Konvergensi Intertropis, suhu muka laut yang hangat, kelembapan udara perlapisan yang tinggi serta udara atas yang labil menyebabkan pertumbahan awan yang banyak di wilayah Jayapura yang kemudian berdampak terhadap terjadinya hujan deras di wilayah tersebut. Analisis citra satelit dapat menunjukkan nilai dan pola yang dapat dijadikan indikasi pertumbuhan awan-awan penghasil hujan lebat.
\end{abstract}

Kata kunci: cuaca ekstrem, bencana hidrometeorologi, analisis cuaca

\section{ABSTRACT}

Rain with intensity $240.0 \mathrm{~mm}$ which occurred on February 22, 2014 in Jayapura, causing floods and landslides in several districts. Weather analysis is required to determine various meteorological factors and to improve preparedness and for reduce the impact of damage and losses due to hydro-meteorological disasters. Data of Sea surface temperatures, sea surface temperature anomaly, southern oscillation index and wind map are visual interpreted. MTSAT Satellite data is processed using SATAID application to generate images and time series graphics of cloud top temperature and cloud top height. Zonal and meridional wind component and relative humidity data are processed using 1.9.0 Grads program to generate vorticity, wind patterns and humidity of each layer of air. Upper air observation data processed using Raob 5.7 application to get the indices of the air stability. The analysis result suggest that clouds development in the Jayapura area caused by Intertropical Convergence Zone, warm sea surface temperatures, high humidity in the air layer and unstable of air thus affects heavy rains in Jayapura. Satellite imagery analysis can suggest the value and patterns that can be used as an indication of clouds development caused heavy rains.

Keywords: extreme weather, hydro-meteorological disasters, weather analysis. 


\section{PENDAhUluan}

Bencana hidrometeorologi berupa banjir dan tanah longsor sangat erat kaitannya dengan terjadinya cuaca ekstrim berupa hujan dengan intensitas tinggi (Ferdiansyah, 2012) selain beberapa faktor seperti sifat fisis permukaan tanah, sistem drainase dan keadaan tanah (Dayantolis dan Hariadi, 2006). Cuaca ekstrem yang sering terjadi di Kabupaten Jayapura menyebabkan wilayah ini sangat berpotensi terjadi bencana hidrometeorologi.

Hujan dengan intensitas sangat lebat sebesar $240.0 \mathrm{~mm}$ yang terjadi pada tanggal 22 Februari 2014 di Kabupaten Jayapura menyebabkan banjir dan tanah longsor dibeberapa distrik. Bencana tersebut telah mengakibatkan 11 orang meninggal dunia, 15 rumah rusak berat dan 40 rumah rusak ringan (BNPB, 2014). Kerugian yang diakibatkan oleh bencana hidrometeorologi dapat dikurangi dengan cara mengetahui faktor-faktor meteorologi yang menyebabkan terjadinya bencana tersebut (Ferdiansyah, 2012;BMKG,2013).

Fenomena cuaca yang terjadi dipengaruhi oleh beberapa faktor meteorologi yang berdasarkan skala meteorologi terbagi menjadi skala global, sinoptik, dan skala meso/lokal (Zakir dkk., 2012). Analisis terhadap skala-skala tersebut dapat membantu untuk mengetahui keterkaitan antar skala tersebut serta unsur cuaca yang paling berpengaruh pada terjadinya fenomena cuaca di suatu tempat (Zakir dkk., 2012; Soera, 2015;Batubara, 2016;Fadholi, 2012). Unsur cuaca pada skala lokal dapat dianalisis menggunakan data dari pengamatan udara atas (Zakir dkk., 2012;Venzke, 2001;AWS, 1990) dan nilai vortisitas selain itu dengan memanfaatkan citra satelit cuaca, pengidentifikasian terhadap suatu fenomena cuaca dapat dengan mudah dilakukan (Subekti, 2012;Afandi, 2012).

Berangkat dari pemikiran tersebut maka diperlukan analisis cuaca untuk mengetahui berbagai faktor meteorologi yang mempengaruhi kondisi cuaca tersebut serta meningkatkan kesiapsiagaan (BMKG, 2013) yang berguna untuk mengurangi dampak kerusakan dan kerugian bahkan timbulnya korban jiwa akibat bencana hidrometeorologi (BNPB, 2012).

\section{TINJAUAN PUSTAKA}

\subsection{Skala Meteorologi}

Identifikasi faktor meteorologi yang mempengaruhi pola cuaca di suatu tempat perlu untuk memperhatikan dinamika cuaca berdasarkan skala meteorologi (BMKG, 2010) karena pada umumnya tidak semua fenomena cuaca disebabkan oleh faktor lokal ataupun sinoptik (Zakir dkk., 2012). Soera (2015), Batubara (2016) dan Setiawan (2012) menyatakan bahwa untuk menganalisis cuaca skala global dapat menggunakan nilai indeks osilasi selatan dan untuk analisis skala sinoptik dapat menggunakan nilai suhu permukaan laut serta peta medan angin sedangkan untuk analisis skala lokal dapat menggunakan indeksindeks kemantapan udara yang didapat dari pengamatan udara serta kelembapan udara dari lapisan permukaan hingga lapisan atas.

\subsection{Pengamatan Udara Atas}

Salah satu tujuan pengamatan udara atas adalah untuk mengetahui kemantapan atmosfer di suatu daerah. Kemantapan atmosfer dapat dianalisis dan diketahui dengan nilai-nilai indeks kemantapan udara yang di dapat dari perhitungan data hasil pengamatan udara atas (Venzke, 2001;AWS, 1990). Indeks-indeks tersebut antara lain Showalter Index (SI), Lifted Index (LI), K Index (KI), Total Totals Index (TTI), Severe Weather Threat (SWEAT) index, Convective Available Potential Energy (CAPE).

\subsection{Vortisitas}

Vortisitas dapat digunakan untuk mendeteksi kecenderungan gerak vertikal udara ke atas. Semakin besar nilai vortisitas maka peluang pertumbuhan awan sangat besar dan cenderung terjadinya hujan (Zakir dkk., 2012).

Untuk Belahan Bumi Utara (BBU) berlaku nilai vortisitas:

(+): udara cenderung bergerak naik ke atas (konveksi)

(-): udara cenderung bergerak turun ke bawah (subsidensi)

Sedangkan untuk Belahan Bumi Selatan (BBS) berlaku nilai vortisitas: 
(+): udara cenderung bergerak turun ke bawah (subsidensi)

(-): udara cenderung bergerak ke atas (konveksi)

\section{METODE PENELITIAN}

\subsection{Data}

Data yang digunakan dalam penelitian ini adalah data tanggal 21-22 Februari 2014. Data tersebut antara lain :

1. Data suhu muka laut dan anomalinya yang didapatkan dari

http://www.weather.unisys.com/archive/sst/ dan data indeks osilasi selatan yang didapatkan dari

http://www.bom.gov.au/climate/current/soi .shtml.

2. Data pengamatan udara atas jam 00.00 UTC dan 12.00 UTC dari Stasiun Meteorologi Penerbangan Biak. Data ini dianggap mewakili kondisi udara atas dari wilayah Jayapura. Data ini diambil dari http://www.weather.uwyo.edu/upperair/soun ding.html.

3. Data komponen angin zonal (u) dan meridional (v) serta kelembapan relatif dalam format .nc yang diambil dari http://www.esrl.noaa.gov/psd/data/gridded/d ata.ncep.reanalysis.pressure.html.

4. Data medan angin dari http://www.bom.gov.au/nmoc/MSL/index.sh tml.

Data satelit MTSAT (Multi-Functional Transport Satelite) kanal IR1 dengan format*.z per jam tanggal 22 Februari 2014 yang di dapat dari basis data BMKG Jakarta.

\subsection{Metodologi}

1. Menganalisis Cuaca Skala Global

Data suhu permukaan laut dan indeks osilasi selatan di interpretasikan secara visual untuk mengetahui faktor global yang mempengaruhi kejadian hujan lebat pada tanggal 22 Februari 2014.

2. Menganalisis Citra Satelit

Data satelit MTSAT diolah menggunakan aplikasi SATAID 6.02 (Satellite Animation and Interactive Diagnosis) untuk menghasilkan luaran berupa gambar dan grafik seri waktu dari suhu puncak awan serta tinggi puncak awan di wilayah Jayapura.

3. Menganalisis Vortisitas, Medan Angin dan Kelembapan Relatif

Data angin komponen zonal (u) dan meridional (v) serta data kelembapan relatif diolah menggunakan program Grads 1.9 .0 sehingga menghasilkan luaran berupa vortisitas dan pola angin serta kelembapan udara pada lapisan $925 \mathrm{mb}, 850 \mathrm{mb}, 700 \mathrm{mb}$ dan $500 \mathrm{mb}$. Pola angin analisis dari BOM dan pola angin keluaran program Grads 1.9.0 tanggal 21-22 Februari 2014 di analisis untuk melihat ada atau tidaknya konvergensi dan belokan angin.

4. Menganalisis Kondisi Udara Atas

Data pengamatan udara atas dalam bentuk sandi Temp diolah menggunakan aplikasi Raob 5.7 untuk mendapatkan indeks-indeks kemantapan udara yang akan digunakan untuk melihat kondisi kemantapan udara pada saat dan sebelum kejadian hujan lebat tanggal 22 Februari 2014. Metode yang digunakan adalah membandingkan nilai indeks dengan klasifikasi indeks kemantapan udara sebagai berikut:

a. LI

Tabel 2. Klasifikasi LI (Zakir dkk., 2010)

\begin{tabular}{|c|c|}
\hline Nilai LI & Prediksi Cuaca \\
\hline $\mathrm{LI}>10$ & $\begin{array}{l}\text { Atmosfer stabil dan } \\
\text { cenderung clear }\end{array}$ \\
\hline $\mathrm{LI}>2$ & $\begin{array}{l}\text { Tidak ada aktivitas } \\
\text { signifikan }\end{array}$ \\
\hline $0<\mathrm{LI}<2$ & $\begin{array}{l}\text { Kemungkinan } \begin{array}{r}\text { Shower, } \\
\text { isolated } \\
\text { possible }\end{array}\end{array}$ \\
\hline$-2<\mathrm{LI}<0$ & Berpeluang badai guruh \\
\hline $\begin{array}{l}-4<\mathrm{LI}<- \\
2\end{array}$ & $\begin{array}{l}\text { Kemungkinan terjadi badai } \\
\text { guruh hebat }\end{array}$ \\
\hline $\mathrm{LI}<-4$ & $\begin{array}{l}\text { Berpeluang badai guruh } \\
\text { hebat, kemungkinan terjadi } \\
\text { tonado }\end{array}$ \\
\hline
\end{tabular}


b. SI

Tabel 1 Klasifikasi SI (AWS Manual, 1961)

\begin{tabular}{|l|l|}
\hline $\begin{array}{l}\text { Nilai SI } \\
\left({ }^{\circ} \mathrm{C}\right)\end{array}$ & Prediksi Cuaca \\
\hline$>3$ & Tidak terjadi Shower \\
\hline 0 s/d 3 & Kemungkinan terjadi Shower \\
\hline-3 s/d 0 & Kemungkinan Thunderstorm \\
\hline-3 s/d -6 & $\begin{array}{l}\text { Kemungkinan } \\
\text { Thunderstorm hebat }\end{array}$ \\
\hline$<-6$ & Kemungkinan terjadi Tornado \\
\hline
\end{tabular}

c. KI

Tabel 3. Klasifikasi KI (AWS, 1990)

\begin{tabular}{|lr|l|}
\hline \multicolumn{2}{|l|}{ Nilai KI } & Peluang Badai Guruh $(\%)$ \\
\hline KI $<15$ & 0 \\
\hline 15 & sampai & 20 \\
20 & & \\
\hline 21 & sampai & $20-40$ \\
25 & & \\
\hline 26 & sampai & $40-60$ \\
30 & & \\
\hline $\begin{array}{l}31 \\
35\end{array}$ & sampai & $60-80$ \\
\hline 36 & sampai & $80-90$ \\
40 & & mendekati 100 \\
\hline KI $>$ & 40 & \\
\hline
\end{tabular}

Tabel 4. Klasifikasi KI (Zakir dkk., 2010)

\begin{tabular}{|l|l|}
\hline KI & Klasifikasi \\
\hline$<15$ & Tidak ada konvektif \\
\hline $15-25$ & $\begin{array}{l}\text { Kemungkinan untuk konvektif } \\
\text { kecil }\end{array}$ \\
\hline $26-39$ & $\begin{array}{l}\text { Kemungkinan untuk konvektif } \\
\text { sedang }\end{array}$ \\
\hline$>40$ & $\begin{array}{l}\text { Kemungkinan untuk konvektif } \\
\text { kuat }\end{array}$ \\
\hline
\end{tabular}

\section{d. TTI}

Tabel 5. Klasifikasi TTI (Zakir, dkk, 2010)

\begin{tabular}{|l|l|}
\hline TTI & Klasifikasi \\
\hline$<44$ & konvektif lemah \\
\hline $44-50$ & konvektif kuat, potensi petir lokal \\
\hline $51-56$ & indikasi cuaca petir meluas \\
\hline$>56$ & $\begin{array}{l}\text { indikasi petir semakin merata } \\
\text { kearah cuaca buruk }\end{array}$ \\
\hline
\end{tabular}

\section{e. SWEAT}

Tabel 6. Klasifikasi SWEAT (Bayong dan Harijono, 2007)

\begin{tabular}{|l|l|}
\hline $\begin{array}{l}\text { Nilai } \\
\text { SWEAT }\end{array}$ & Prakiraan Cuaca \\
\hline $\begin{array}{l}170 \text { sampai } \\
203\end{array}$ & Pertumbuhan awan Cumulus \\
\hline $\begin{array}{l}230 \text { sampai } \\
250\end{array}$ & Mungkin terjadi badai guruh \\
\hline $\begin{array}{l}\text { SWEAT }> \\
250\end{array}$ & $\begin{array}{l}\text { Mungkin terjadi badai guruh } \\
\text { kuat }\end{array}$ \\
\hline
\end{tabular}




\section{f. CAPE}

Tabel 7. Klasifikasi CAPE ( Djuric dalam Zakir dkk., 2010)

\begin{tabular}{|l|l|}
\hline CAPE $\left(\mathbf{J k g}^{-1}\right)$ & Klasifikasi \\
\hline$<1000$ & Konvektif lemah \\
\hline $1000-2500$ & Konvektif sedang \\
\hline$>2500$ & Konvektif kuat \\
\hline
\end{tabular}

\section{HASIL DAN PEMBAHASAN}

\subsection{Osilasi Selatan dan Suhu Muka Laut}

Gambar 1 menunjukkan bahwa pada bulan Februari 2014 indeks osilasi selatan bernilai 1.3. Nilai ini tergolong dalam kategori normal $(-8-+8)$ sehingga tidak terlalu memberikan pengaruh terhadap penambahan maupun pengurangan jumlah curah hujan di wilayah Indonesia khususnya Indonesia bagian Timur.

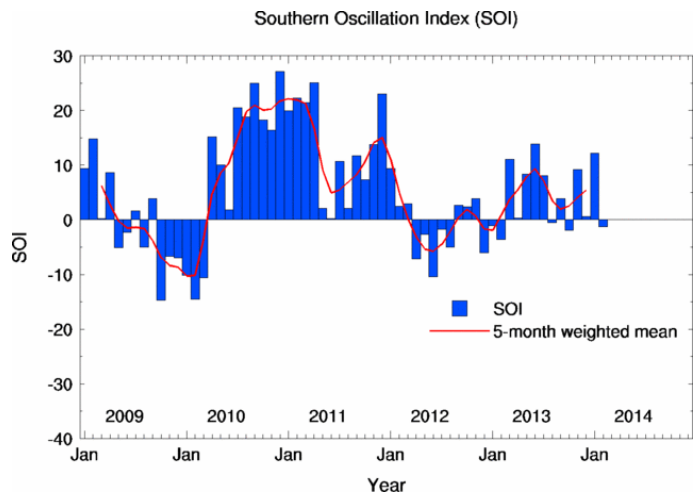

Gambar 1. Indeks Osilasi Selatan Bulan Januari 2009 Sampai Januari 2014

Pada Gambar 2.a terlihat bahwa suhu muka laut di perairan Utara Jayapura bernilai di atas $28{ }^{\circ} \mathrm{C}$ dengan anomali sebesar $0.5{ }^{\circ} \mathrm{C}$ (Gambar 2.b). Hal ini menunjukkan bahwa perairan sebelah Utara Papua cukup hangat dan memiliki kandungan uap air yang cukup untuk mendukung pembentukan awan di sekitar daerah tersebut.
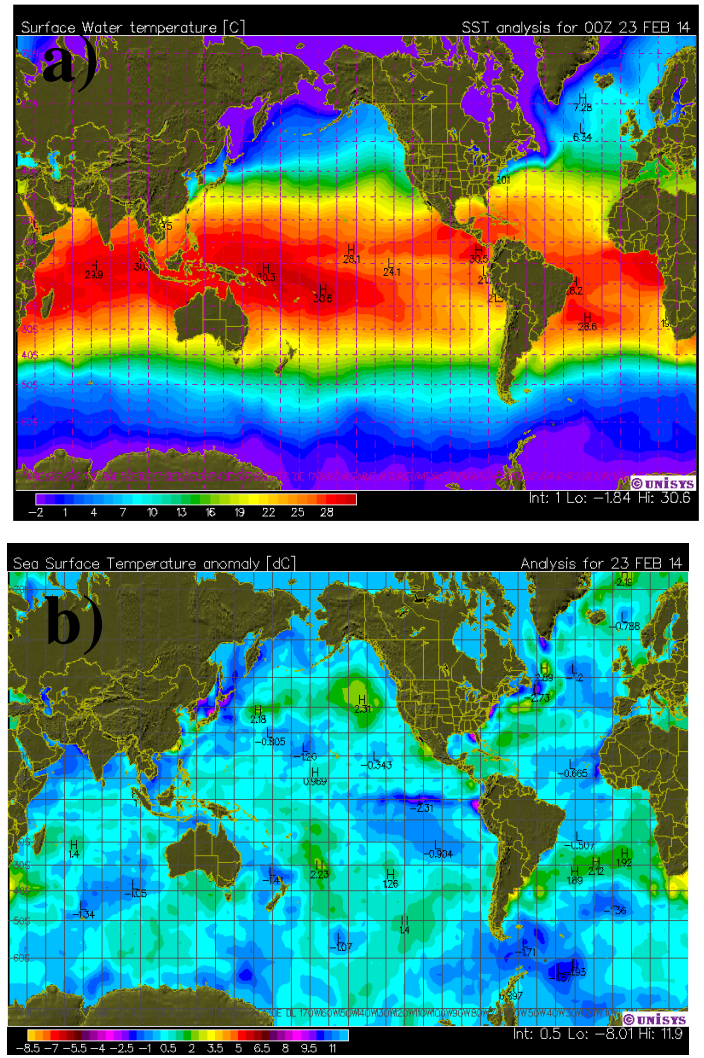

Gambar 2. (a) Suhu Muka Laut Tanggal 23 Februari 2014, (b) Anomali Suhu Muka Laut Tanggal 23 Februari 2014

\subsection{Medan Angin dan Vortisitas}

Gambar 3 (g) dan (h) menunjukkan bahwa umumnya angin bertiup dari Barat Daya. Satu hari sebelum kejadian hujan lebat, pola angin di atas Jayapura dan sekitarnya tidak terdapat gangguan berupa konvergensi. Perubahan pola angin terjadi pada tanggal 22 Februari 2014 (Gambar 3.h) terlihat dengan adanya Daerah Konvergensi Intertropis (DKIT) di sekitar wilayah Jayapura sehingga memungkinkan terjadi pertumbuhan awan dan hujan yang sangat lebat di wilayah tersebut. Dari Gambar 4 (a) sampai (f) dapat dilihat nilai vortisitas per lapisan dari tanggal 21 sampai 22 Februari 2014 bernilai negatif (-) dimana terjadi penurunan nilai vortisitas dari tanggal 21 hingga tanggal 22 Februari 2014. Keadaan ini menunjukkan bahwa atmosfer pada tanggal 21 sampai 22 Februari 2014 menjadi lebih tidak stabil dari hari sebelumnya. Atmosfer yang tidak stabil ini memungkinkan terjadi pertumbuhan awan dan badai guruh yang cukup intensif. 
a)

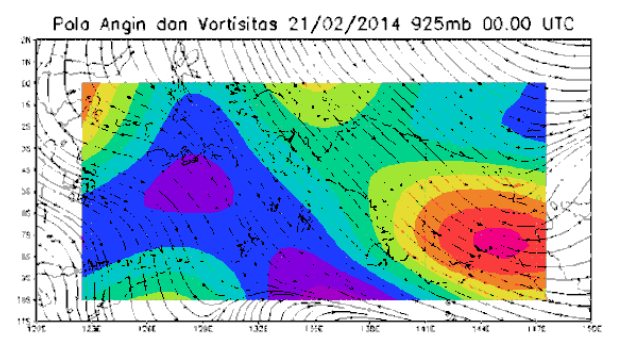

b)

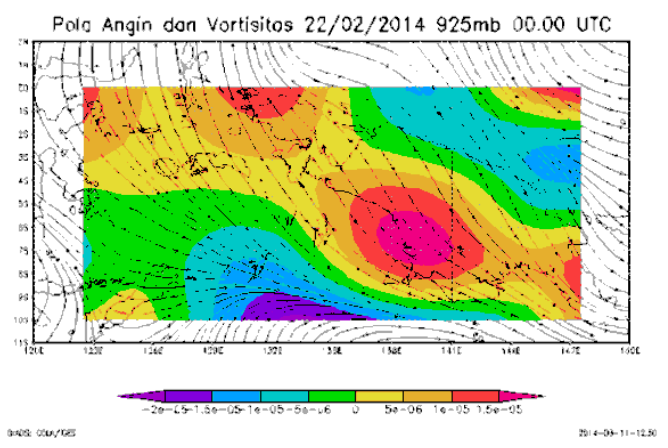

c)

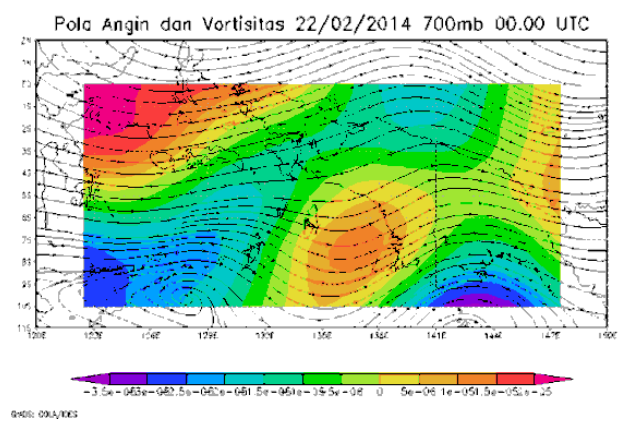

d)
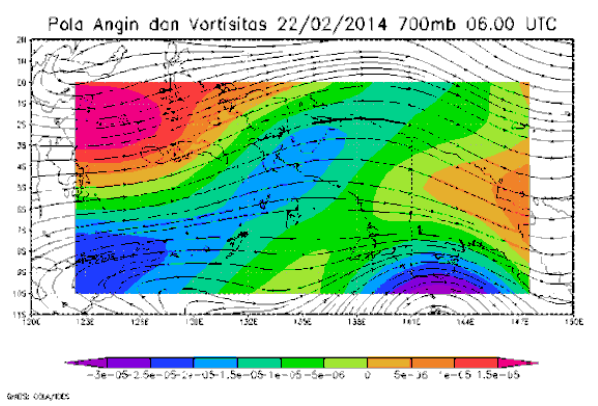

e)

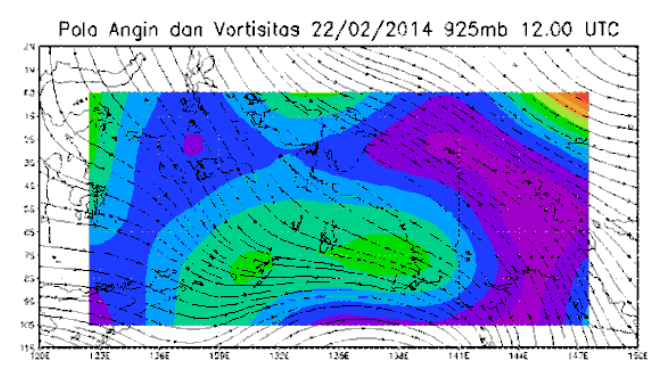

f)

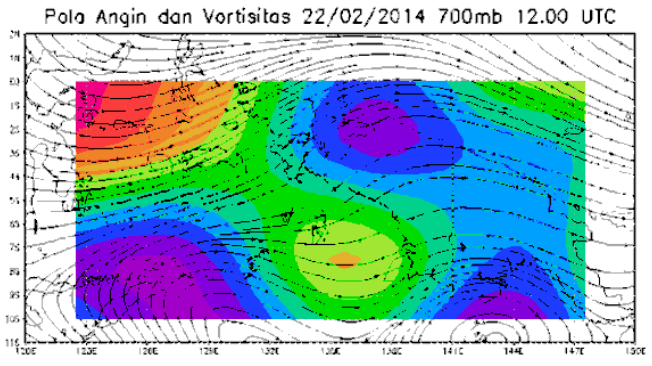

g)

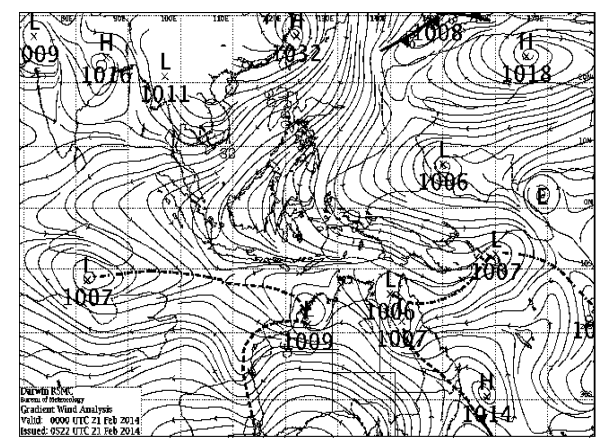

h)

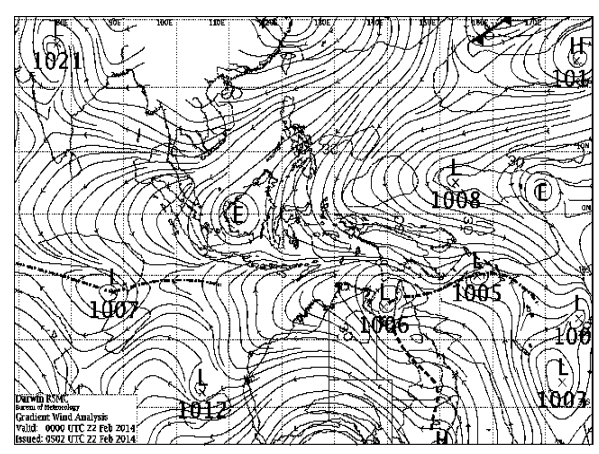

Gambar 3. (a), (b), (c), (d), (e), (f) Vortisitas Tiap Lapisan dan (g), (h) Medan Angin Tanggal 21-22 Februari 2014 


\subsection{Kemantapan Udara}

Tabel 8 menunjukkan nilai SI pada tanggal 2122 Februari 2014 berada pada rentang -1 hingga +1 yang mengindikasikan kemungkinan terjadi shower dan badai guruh. Nilai LI pada tanggal 21-22 Februari 2014 umumnya berada pada rentang -3 hingga -1 . Ini mengindikasikan kemungkinan adanya badai guruh. Nilai KI pada tanggal 21-22 Februari 2014 terlihat meningkat dan umumnya berada pada rentang 30-39. Ini mengindikasikan kemungkinan terjadi konvektif sedang dengan kemungkinan TS antara $60-90 \%$. Nilai KI pada tanggal 22
Februari 2014 menunjukkan peluang TS sebesar $80-90 \%$. TTI pada tanggal 21 berada pada rentang 42-44 yang mengindikasikan konfektif lemah. Sedangkan pada tanggal 22 Februari 2014 TTI berada pada rentang nilai 43-45 yang menunjukkan kemungkinan konvektif kuat dengan potensi petir lokal. Indeks SWEAT dan CAPE dari tanggal 21 hingga 22 Februari 2014 mengalami peningkatan dimana nilai tertinggi yaitu pada tanggal 22 Februari 2014 dengan kemungkinan terjadi badai guruh hebat dan konvektif sedang.

Tabel 8. Nilai Indeks Kemantapan Udara

\begin{tabular}{|l|l|l|l|l|l|l|l|}
\hline $\begin{array}{l}\text { TANGGAL / } \\
\text { INDEX }\end{array}$ & $\begin{array}{l}\text { JAM } \\
\text { (UTC) }\end{array}$ & SI & LI & KI & TTI & SWEAT & CAPE \\
\hline \multirow{2}{2}{$\begin{array}{l}\text { S Februari } \\
2014\end{array}$} & 00.00 & 0.29 & -1.43 & 30.80 & 44.30 & 235.21 & 232.37 \\
\cline { 2 - 8 } & 12.00 & 0.71 & -1.61 & 32.70 & 42.00 & 260.20 & 1185.91 \\
\hline \multirow{2}{2}{$\begin{array}{l}2014 \\
2\end{array}$} & 00.00 & -0.99 & -2.78 & 38.8 & 44.80 & 261.40 & 1146.96 \\
\cline { 2 - 8 } & 12.00 & 0.43 & -2.50 & 35.50 & 42.60 & 258.20 & 1374.70 \\
\hline
\end{tabular}

\subsection{Kelembapan Udara}

Pada Grafik 1 dan Tabel 9 terlihat bahwa terjadinya peningkatan kelembapan udara dari tanggal 21-22 Februari 2014 terutama pada lapisan $700 \mathrm{mb}$ yang meningkat hingga sekitar $20 \%$. Kelembapan udara per lapisan dari tanggal 21-22 Februari 2014 bernilai antara 55-
90\% yang menunjukkan kondisi atmosfer disekitar wilayah Jayapura sangat lembab. Pada tanggal 22 Februari 2014 kelembapan udara per lapisan sangat tinggi. Ini menunjukkan bahwa lapisan udara lembap cukup tebal sehingga sangat mendukung dalam pembentukan awan yang dapat menghasilkan hujan yang lebat di wilayah Jayapura.

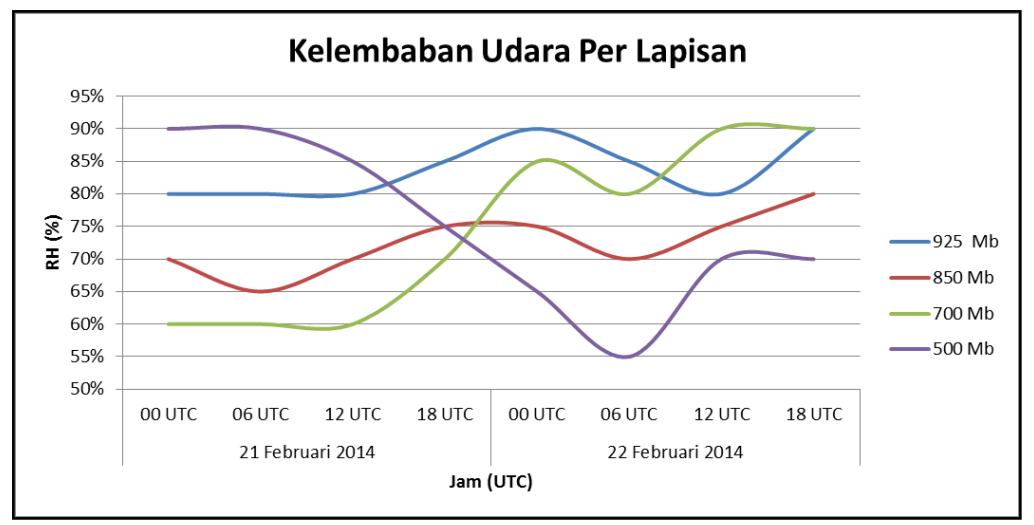

Grafik 1. Kelembapan Udara Per Lapisan Tanggal 21-22 Februari 2014 Jam 00.00 Sampai 18.00 UTC 
Tabel 9. Kelembapan Udara Tiap Lapisan Jam 00.00 Dan 12.00 UTC Tanggal 21-22 Februari 2014

\begin{tabular}{|l|l|l|l|l|l|}
\hline \multicolumn{1}{|l|}{ TANGGAL / LAPISAN } & $925 \mathrm{mb}$ & $850 \mathrm{mb}$ & $700 \mathrm{mb}$ & $500 \mathrm{mb}$ \\
\hline \multirow{5}{*}{$21 / 02 / 2014$} & $\begin{array}{l}00.00 \\
\text { UTC }\end{array}$ & $80-85 \%$ & $70-75 \%$ & $60-65 \%$ & $90-95 \%$ \\
\cline { 2 - 6 } & $\begin{array}{l}06.00 \\
\text { UTC }\end{array}$ & $80-85 \%$ & $65-70 \%$ & $60-65 \%$ & $>90 \%$ \\
\cline { 2 - 6 } & $\begin{array}{l}12.00 \\
\text { UTC }\end{array}$ & $80-85 \%$ & $70-75 \%$ & $60-70 \%$ & $85-90 \%$ \\
\cline { 2 - 6 } & $\begin{array}{l}18.00 \\
\text { UTC }\end{array}$ & $85-90 \%$ & $75-80 \%$ & $70-80 \%$ & $75-80 \%$ \\
\hline \multirow{2}{*}{$22 / 02 / 2014$} & $\begin{array}{l}00.00 \\
\text { UTC }\end{array}$ & $90-95 \%$ & $75-80 \%$ & $>85 \%$ & $65-70 \%$ \\
\cline { 2 - 6 } & $\begin{array}{l}06.00 \\
\text { UTC }\end{array}$ & $85-90 \%$ & $70-75 \%$ & $80-90 \%$ & $55-60 \%$ \\
\cline { 2 - 6 } & $\begin{array}{l}12.00 \\
\text { UTC }\end{array}$ & $80-85 \%$ & $75-80 \%$ & $>90 \%$ & $70-75 \%$ \\
\hline & $\begin{array}{l}18.00 \\
\text { UTC }\end{array}$ & $90-95 \%$ & $80-85 \%$ & $90-100 \%$ & $70-75 \%$ \\
\hline
\end{tabular}

\subsection{Citra Satelit}

Dari Gambar 4.a memperlihatkan pada pukul 11.00 UTC adanya pembentukan awan di wilayah Jayapura dengan suhu puncak awan di sekitar wilayah Jayapura yang sudah berada di bawah titik beku yaitu -25 hingga $-35^{\circ} \mathrm{C}$ (Gambar 4.b). Pada pukul 12.00 UTC terdapat awan-awan konvektif dengan suhu puncak awan antara -30 hingga $-50^{\circ} \mathrm{C}$ (Gambar 4.d). Pada gambar 4.e menunjukkan adanya tutupan awan yang cukup luas di wilayah Jayapura pada pukul 14.00 UTC dengan nilai suhu puncak awan yang semakin menurun berkisar antara 75 hingga $-80^{\circ} \mathrm{C}$ (Gambar 4.f) yang mengindikasikan adanya awan-awan konvektif di wilayah tersebut. Nilai suhu puncak awan yang semakin kecil ini juga dapat menjadi indikasi adanya potensi terjadi hujan lebat. Hingga jam 20.00 UTC daerah tutupan awan masih cukup luas di wilayah Jayapura (Gambar 4.g) namun menunjukkan adanya peluruhan awan dengan berkurangnya suhu puncak awan yang berkisar antara -60 hingga $-70^{\circ} \mathrm{C}(\mathrm{Gambar}$ 4.h). 


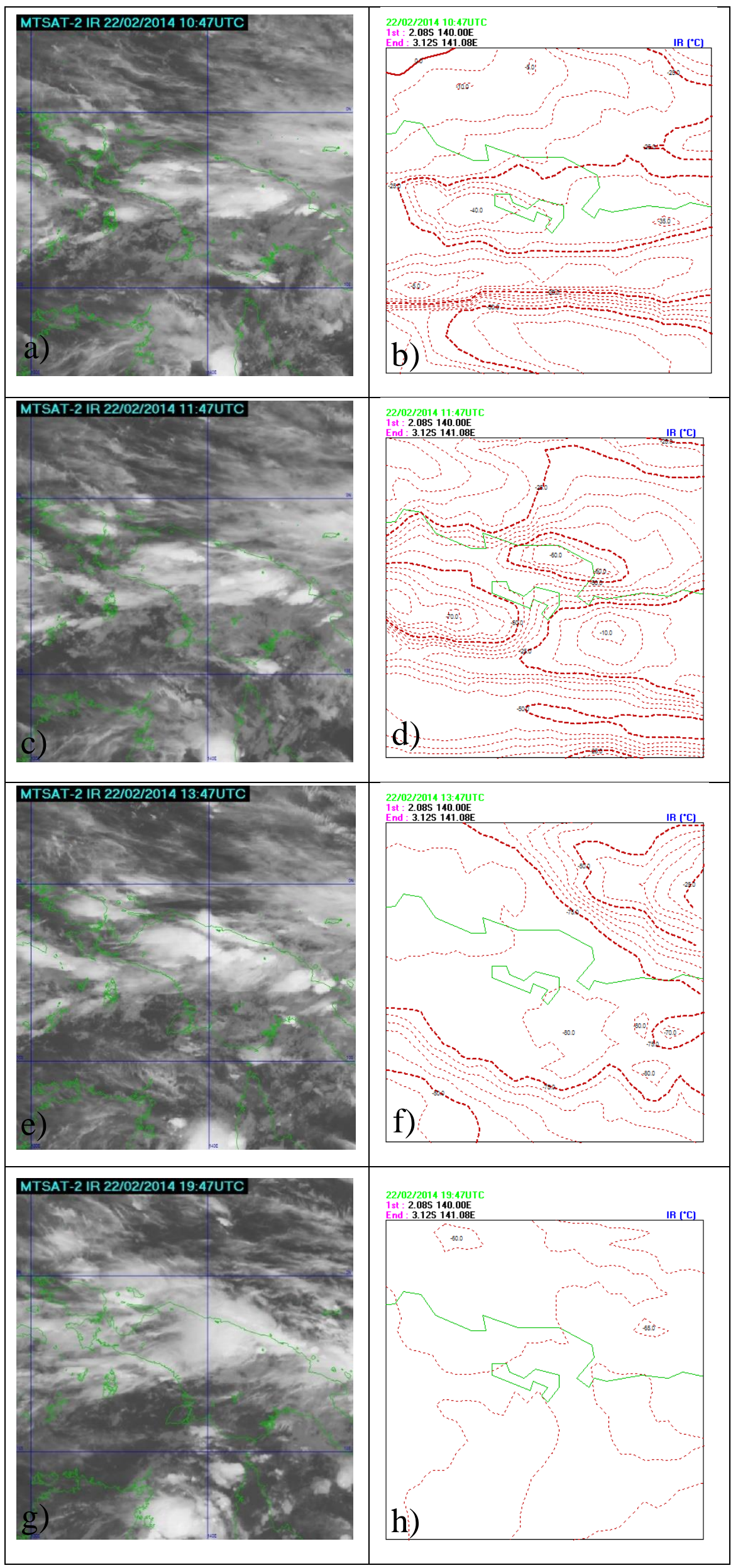


Gambar 4. (a), (c), (e), (g) Citra Satelit MTSAT Kanal IR1, (b), (d), (f), (h) Kontur

Suhu Puncak Awan Tanggal 22 Februari 2014

Pada Gambar 5 (a) dan (b) menunjukkan bahwa adanya kesamaan pola kenaikan tinggi puncak awan dengan penurunan suhu puncak awan. Penelitian yang dilakukan oleh Subekti (2012) dan P. (2012) juga menunjukkan pola yang sama antara suhu puncak awan dan tinggi puncak awan pada kasus hujan lebat. Suhu puncak awan di wilayah Jayapura pada jam 10.00 UTC hingga 13.00 UTC mengalami penurunan suhu yang cukup signifikan (Gambar 5.a). Penurunan suhu tersebut dari $19^{\circ} \mathrm{C}$ menjadi $-80^{\circ} \mathrm{C}$ sehingga nilai penurunan suhu terjadi sebesar $-61^{\circ} \mathrm{C}$ (Gambar 5.a). Pada Gambar 5.b menunjukkan bahwa terjadi peningkatan tinggi puncak awan yang cukup signifikan pada jam 10.00 UTC hingga 13.00 UTC dari lapisan sekitar $400 \mathrm{mb}$ menjadi sekitar $100 \mathrm{mb}$. Hal ini sesuai dengan penelitian sebelumnya, yang menunjukkan bahwa adanya penurunan suhu puncak awan dan peningkatan tinggi puncak awan yang cukup signifikan dari beberapa jam sebelumnya pada kasus hujan lebat. Penurunan suhu puncak awan dan kenaikan tinggi puncak awan yang cukup signifikan ini dapat menjadi indikasi adanya pertumbuhan awan konvektif dan hujan sedang hingga lebat di wilayah Jayapura.

a)

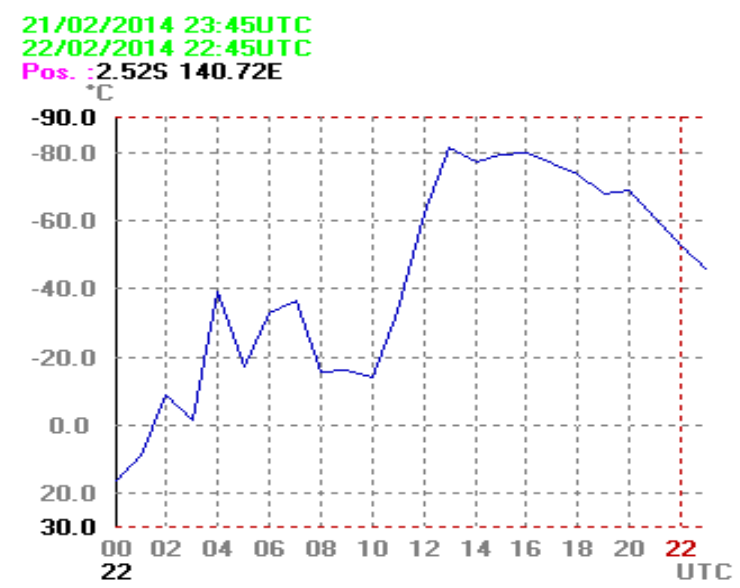

b)

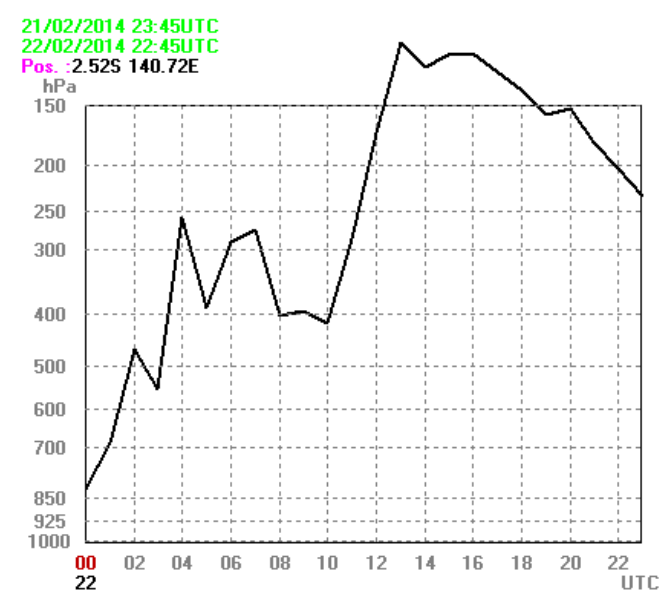

Gambar 5. (a) Grafik Seri Waktu Suhu Puncak Awan, (b) Grafik Seri Waktu Tinggi Puncak Awan di Wilayah Jayapura Tanggal 22 Februari 2014

\section{KESIMPULAN}

Didapatkan beberapa kesimpulan sebagai berikut :

1. Suhu muka laut yang hangat di perairan sebelah Utara Jayapura mendukung dalam menyuplai uap air di sekitar wilayah tersebut.

2. Pola angin pada tanggal 22 Februari 2014 menunjukkan adanya DKIT di sekitar wilayah Jayapura. Gangguan cuaca ini mendukung pembentukan awan di sekitar wilayah Jayapura.

3. Nilai vortisitas yang negatif hingga lapisan atas turut mendukung dalam pembentukan awan di sekitar wilayah Jayapura pada tanggal 22 Februari 2014.

4. Terjadinya peningkatan ketidakmantapan atmosfer dari tanggal 21 hingga 22 Februari 2014. Nilai ketidakmantapan terbesar terjadi pada tanggal 22 Februari 2014 yang menandakan bahwa kondisi atmosfer sangat mendukung untuk pertumbuhan awan di wilayah Jayapura

5. Adanya kenaikan nilai kelembapan udara terutama pada lapisan $700 \mathrm{mb}$ yang meningkat hingga sekitar $20 \%$ dari hari sebelumnya. Kelembapan udara yang tinggi 
pada lapisan 925, 850, 700 dan $500 \mathrm{mb}$ pada tanggal 22 Februari 2014 memberikan kontribusi terhadap pembentukan awan di wilayah Jayapura.

6. Hasil analisis citra satelit menunjukkan adanya penurunan nilai suhu puncak awan yang cukup signifikan sekitar $-61^{\circ} \mathrm{C}$ serta kenaikan tinggi puncak awan yang cukup signifikan. Nilai dan pola tersebut dapat dijadikan indikasi pertumbuhan awan-awan penghasil hujan lebat di wilayah Jayapura.

\section{UCAPAN TERIMA KASIH}

Penulis berterimakasih secara khusus kepada:

1. Bapak Parmin selaku Kepala Stasiun Meteorologi Kelas I Hang Nadim Batam.

2. Bapak Suratman selaku Kasi Datin Stasiun Meteorologi Kelas I Hang Nadim Batam.

3. Rekan-rekan Forecaster Stasiun Meteorologi Kelas I Hang Nadim Batam.

\section{DAFTAR PUSTAKA}

Afandi, R. 2012. Identifikasi Cuaca Ekstrim Melalui Pemanfaatan Citra Satelit MTSAT (Studi Hujan Sangat Lebat Jayapura 18-19 Juli 2012). Prosiding Workshop Cuaca Ekstrim 2012 Volume 1 Nomor 19 - November 2012: 27-31.

AWS. 1990. The Use of The Skew T, $\log P$ Diagram in Analysis and Forecasting. Scott Air Force Base. Illinois.

AWS Manual. 1961. Use of The Skew T, $\log P$ Diagram in Analysis and Forecasting (Radiosonde Analysis). Scott Air Force Base. Illinois.

Batubara, M.P.N. 2016. Dinamika Meteorologis Terkait Penurunan Curah Hujan di Batam Februari 2014.

BKMG. 2010. Peraturan Kepala Badan Meteorologi, Klimatologi dan Geofisika Tentang Prosedur Standar Operasional Pelaksanaan Peringatan Dini, Pelaporan, dan Diseminasi Informasi Cuaca Ekstrim. Jakarta: BMKG.

BMKG. 2013. Jangan Abaikan Informasi Cuaca. InfoBMKG Edisi 02/2013: 4-5.
BNPB. 11 Tewas Tertimbun Longsor di KotaJayapura.(http://www.bnpb.go.id/ne ws/read/1939/11-tewas-tertimbunlongsor-di-kota-jayapura diakses tanggal 14 Maret 2014).

BNPB. 2012. Waspada Masyarakat pada Bencana Angin Puting Beliung dan Banjir. Gema BNPB Volume 3 Nomor 3 - November 2012: 25-27.

Dayantolis, W. dan Hariadi. 2006. Analisa Kondisi Fisis Atmosfer Pada Saat Hujan Ekstrim dan Terjadinya Banjir Bulan Februari 2006 di Manado. Jurnal Meteorologi Dan Geofisika Volume 7 Nomor 3 - September 2006: 30-41.

Fadholi, A. 2012. Analisa Kondisi Atmosfer Pada Kejadian Cuaca Ekstrem Hujan Es (Hail). Prosiding Workshop Cuaca Ekstrim 2012 Volume 1 Nomor 19 November 2012: 71-77.

Ferdiansyah, A. 2012. Potensi Parameter Keluaran Raob (Rawinsonde Observation Programs) Sebagai Indikator Kunci Dalam Analisis Curah Hujan. Skripsi Jurusan Meteorologi Terapan, Institut Pertanian Bogor, Bogor.

Bony, S. 2012. Analisis Kejadian Cuaca Ekstrim Tanggal 24-25 Mei di Balikpapan Menggunakan Software Sataid dan Pembandingannya dengan Hasil Prognosa Model Arpege (Synergie) Sebagai Bahan Pertimbangan Peringatan Dini Cuaca Ekstrim. Prosiding Workshop Cuaca Ekstrim 2012 Volume 1 Nomor 19 - November 2012: 86-93.

Setiawan, P. A. 2012. Teknik Pembuatan Analisis Cuaca Ekstrem. Prosiding Workshop Cuaca Ekstrim 2012, Volume 1 Nomor 19 - November 2012: 127-130.

Soera, L.S. 2015. Kajian Meteorologi Terkait Cuaca Ekstrem Saat Musim Kemarau (Studi Kasus Hujan Sangat Lebat 17 - 26 Juni 2013 di Malaka - NTT). Skripsi, Program Sarjana Terapan Meteorologi, Sekolah Tinggi Meteorologi Klimatologi Dan Geofisika.

Subekti, R. 2012. Deteksi dan Analisa Hujan Lebat - Angin Kencang dan Banjir dengan Menggunakan Aplikasi Sataid: Studi Kasus Bandar Lampung dan Lampung Tengah. Prosiding Workshop 
Cuaca Ekstrim 2012 Volume 1 Nomor 19 - November 2012: 17-22.

Tari, C. A., 2010. Analisis Terjadinya Banjir di Kabupaten Belu Propinsi Nusa Tenggara Timur Pada Tanggal 5-7 Mei 2009. Buletin Meteorologi Klimatologi dan Geofisika, Volume 6 Nomor 3 September 2010: 268-273.

Bayong, T. H. K. 2008. Meteorologi Terapan. ITB. Bandung.

Bayong, T. H. K. 2004. Klimatologi Edisi Kedua. ITB. Bandung.
Bayong, T. H. K., Harijono, Sri W. B. 2007. Meteorologi Indonesia 2 Awan \& Hujan Monsun. BMG. Jakarta.

Venzke, K. C. 2001. Development of Predictors for Cloud-to-Ground Lightning Activity using Atmospheric Stability Indices. Thesis. Air Force Institute Of Technology. Wright-Patterson Air Force Base, Ohio.

Zakir, A., Sulistya, W., Khotimah, dan Mia, K. 2010. Perspektif Operasional Cuaca Tropis. BMKG. Jakarta 
